\title{
JOURNAL OF ADVANCEMENT IN
}

\section{ENGINEERING AND TECHNOLOGY}

Journal homepage: http://scienceq.org/Journals/JAET.php

\section{E-commerce websites using jQ.Mobi}

Seifedine kadry ${ }^{1 *}$, Mohammed Z. Al-Taie ${ }^{2}$

1. Engineering School, American University of the Middle East, Egaila, Kuwait.

2. CS Department, Al-Salam University College, Iraq.

\author{
*Corresponding author: Seifedine kadry \\ Engineering School, \\ American University of the Middle East, \\ Egaila, Kuwait. \\ E-mail: skadry@gmail.com
}

Received: December 30, 2013, Accepted: January 8, 2014, Published: January 13, 2014.

\section{ABSTRACT}

In the present epoch, it's impossible to live one day without internet. The applications of internet are widely used in E-business and especially in E-Commerce. E-commerce is the use of the Internet and the Web to transact business. It is digitally enabled commercial transactions between and among organizations and individuals. In a recent performance test conducted by Aberdeen's, widely accepted performance stat, showed that a 1 -second delay in web page load time equals $11 \%$ fewer page views, a $16 \%$ decrease in customer satisfaction, and 7\% loss in conversions (In dollar terms, this means that if your site typically earns $\$ 100,000$ a day, this year you could lose $\$ 2.5$ million in sales). Therefore there is a need to build up faster loading web pages. Using jQ.Mobi, we can create faster loading eye catching web pages. In this paper, we study the performance and the advantages of jQ.Mobi against other technologies through mobile application.

Keywords: E-commerce; jabascript; jQ.Mobi; jQuery

\section{INTRODUCTION}

E-Commerce is defined as the buying and selling of products or services over electronic systems. A wide variety of commerce is conducted via e-commerce, including electronic funds transfer, supply chain Management, online transaction processing, electronic data interchange (EDI) and automated data collection systems. It also pertains to any form of business transaction in which the parties interact electronically rather than by physical exchanges or direct physical contact. E-Commerce is very widely used in the developed countries to enhance productivity, efficiency, accuracy and security [7].

E-commerce website is very valuable for the product sellers and service providers. Customers can directly buy the product from any website by online payment; the items will be dispatched to their given address. Recently, a web performance test conducted by Aberdeen's[6], widely accepted web performance stat, showed that a 1-second delay in web page load time equals $11 \%$ fewer page views, a $16 \%$ decrease in customer satisfaction, and 7\% loss in conversions (In dollar terms, this means that if your site typically earns $\$ 100,000$ a day, this year you could lose \$2.5 million in sales). Consequently, developing faster loading web pages is a must [3]. Using jQ.Mobi, open source JavaScript framework developed by appMobi, we can create faster loading noticeable web pages. In this paper, we study the performance and the advantages of jQ.Mobi against other technologies through mobile application.

\section{ADVANTAGES OF E-COMMERCE}

In present era, ecommerce is widely used in different field mentioned above. E-Commerce can increase sales and decrease costs. The internet and the web are particularly useful in creating virtual communities that become ideal target markets [4].

A virtual community is a gathering of people who share a common interest, but, instead of this gathering occurring in the physical world it takes place on the internet.

Just as E-Commerce increases sales opportunities for the seller, it increases purchasing opportunities for the buyer. Businesses can use E-commerce in their purchasing processes to identify new suppliers and business partners.

Negotiating price and delivery terms is easier in E-commerce, because the web can provide competitive bid information very efficiently. E-Commerce increases the speed and accuracy with which businesses can exchange information, which reduces costs on both sides of transactions. 
E-Commerce provides buyers with a wider range of choices than traditional commerce, because they can consider many different products and services from a wider variety of sellers. The benefits of E-Commerce also extend to the general welfare of society. Electronic payments of tax refunds, public retirement, and welfare support cost less to issue and arrive securely and quickly when transmitted via the Internet. Furthermore, electronic payments can be easier to audit and monitor than payments made by check, which can help protect against fraud and theft losses. E-Commerce can make products and services available in remote areas. For example, distance education is making it possible for people to learn skills and earn degrees no matter where they live or what hours of the day they have available for study [7].

\section{CATEGORIES OF E-COMMERCE}

There are a variety of different types of e-commerce and many different ways to characterize these types. Table 1 lists the five major types of e-commerce [2].

Table 1: the five major types of e-commerce

\begin{tabular}{|l|l|}
\hline \multicolumn{1}{|c|}{ Category of E-commerce } & \multicolumn{1}{|c|}{ Example } \\
\hline B2C-Business-to-Consumer & $\begin{array}{l}\text { Amazon.com is a general } \\
\text { merchandiser that sells } \\
\text { consumer products to retail } \\
\text { consumers. }\end{array}$ \\
\hline B2B-Business-to-Business & $\begin{array}{l}\text { ChemConnect.com is a } \\
\text { chemical industry exchange } \\
\text { that creates an electronic } \\
\text { market for chemical } \\
\text { producers and users. }\end{array}$ \\
\hline C2C-Consumer-to-Consumer & $\begin{array}{l}\text { eBay.com creates a market } \\
\text { space where consumers can } \\
\text { auction or sell goods directly } \\
\text { to other consumers. }\end{array}$ \\
\hline P2P-Peer-to-Peer & $\begin{array}{l}\text { Gnutella is a software } \\
\text { application that permits } \\
\text { consumers to share music } \\
\text { with one another directly, } \\
\text { without the intervention of a } \\
\text { market maker as in C2C } \\
\text { e-commerce }\end{array}$ \\
\hline $\begin{array}{l}\text { Wireless mobile devices } \\
\text { such as PDAs (personal } \\
\text { digital assistants) or cell } \\
\text { phones can be used to } \\
\text { conduct commerce-Mobile } \\
\text { transactions. commercial }\end{array}$ \\
\hline
\end{tabular}

\section{A.Business-to-Consumer (B2C)}

The most commonly discussed type of e-commerce is Business-to-Consumer (B2C) e-commerce, in which online businesses attempt to reach individual consumers. Even though B2C is comparatively small ( $\$ 140-\$ 170$ billion in 2005), it has grown exponentially since 1995, and is the type of e-commerce that most consumers are likely to encounter. Within the B2C category, there are many different types of business models.
Chapter 2 has a detailed discussion of seven different B2C business models: portals, online retailers, content providers, transaction brokers, market creators, service providers, and community providers.

\section{B. Business-to-Business (B2B)}

Business-to-Business (B2B) e-commerce, in which businesses focus on selling to other businesses, is the largest form of e-commerce, with over $\$ 1.5$ trillion in transactions in the United States in 2005. There was an estimated \$13 trillion in business-to-business exchanges of all kinds, online and offline, in 2002, suggesting that B2B e-commerce has significant growth potential (eMarketer, Inc., 2003). The ultimate size of B2B e-commerce could be huge. There are two primary business models used within the B2B arena: Net marketplaces, which include e-distributors, e-procurement companies, exchanges and industry consortia, and private industrial networks, which include single firm networks and industry-wide networks.

\section{C.Consumer-to-Consumer (C2C)}

Consumer-to-Consumer (C2C) e-commerce provides a way for consumers to sell to each other, with the help of an online market maker such as the auction site eBay.

Given that in 2005, eBay generated more than $\$ 44$ billion in gross merchandise volume around the world, it is probably safe to estimate that the size of the global C2C market in 2006 will be over $\$ 50$ billion (eBay, 2006). In C2C e-commerce, the consumer prepares the product for market, places the product for auction or sale, and relies on the market maker to provide catalog, search engine, and transaction-clearing capabilities so that products can be easily displayed, discovered, and paid for.

\section{D.Peer-to-Peer (P2P) E-commerce}

Peer-to-peer technology enables Internet users to share files and computer resources directly without having to go through a central Web server. In peer-to-peer's purest form, no intermediary is required, although in fact, most P2P networks make use of intermediary "super servers" to speed operations. Since 1999, entrepreneurs and venture capitalists have attempted to adapt various aspects of peer-to-peer technology into Peer-to-Peer (P2P) e-commerce. To date there have been very few successful commercial applications of P2P e-commerce with the notable exception of illegal downloading of copyrighted music.

\section{E.Mobile Commerce (M-commerce)}

Mobile commerce, or m-commerce, refers to the use of wireless digital devices to enable transactions on the Web. $\mathrm{m}$-commerce involves the use of wireless networks to connect cell phones, handheld devices such Blackberries, and personal computers to the Web. Once connected, mobile consumers can conduct transactions, including stock trades, in-store price comparisons, banking, travel reservations, and more. Thus far, m-commerce is used most widely in Japan and Europe (especially in Scandinavia), where cell phones are more prevalent than in the United States; however, as discussed in the next section, m-commerce is expected to grow rapidly in the United States over the next five years. 


\section{JAVASCRIPT FRAMEWORKS [8]}

A. The jQuery library was originally designed for desktop browsers, with cross-browser compatibility as a major goal. Since fragmentation on the desktop is worse than on mobile devices, jQuery comes with some additional weight not really needed for mobile devices. Therefore, new jQuery compatible libraries specifically designed for mobile browsers have surfaced.

B. Zepto (also called Zepto.js) aims to be smaller and load faster than jQuery. It supports both modern desktop browsers and mobile browsers (with the exception of Internet Explorer).

C. jQ.Mobi is a JavaScript framework in the same vein as Sencha Touch, JQuery Mobile and JQTouch. Unlike those frameworks, which are built in HTML4 and rooted in Web browsers, jQ.Mobi is an HTML5 rewrite of the jQuery framework.

The below figures show the comparison between these frameworks in terms of code size and speed.

\section{Code Size}
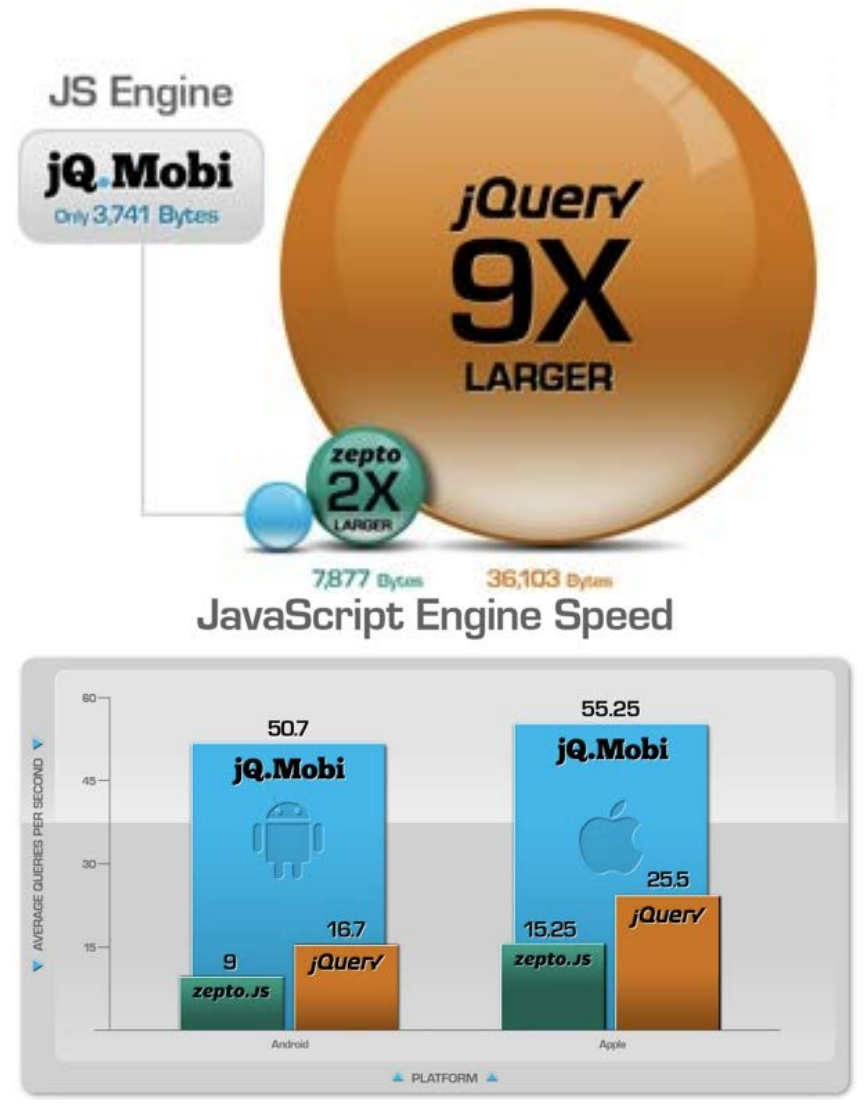

\section{SIMULATION AND RESULTS}

In this section, we will compare the performance of the libraries in terms of page loading time. We use the JS Framework Benchmark [1] to test our mobile application. The application runs without any modifications on Android and iOS operating systems.

The app has a Web user interface, with a web widget component (Web widgets are small programs embedded directly into web pages. They are quite useful, and some users build entire home pages with them) that runs on top of a thin layer of Java. The Java layer contains code that measures startup time and page load time. The web widget contains JavaScript code that does the Document Object Model (DOM) [5-6], which is a cross-platform and language-independent convention for representing and interacting with objects in HTML.

The application uses the same source code for each library. We did not need to make any modifications to the application source code when switching between libraries.

The platforms tested include: Android (Samsung) and iOS (iPhone, iPad). We used the following versions of the libraries:

- jQuery 1.7.2 minified

- Zepto 1.0rc1 minified

- jqMobi 1.03 minified

Our application tests the following:

$\square$ Page loading time

$\square$ Performance of DOM manipulation:

- Create DOM elements (create + style + add)

- Modify DOM elements (access + modify text)

- Delete DOM elements (access + remove)

For each type of DOM operation, the application makes 5000 iterations. The numbers of milliseconds for each 5000 iterations are shown in the figures below.
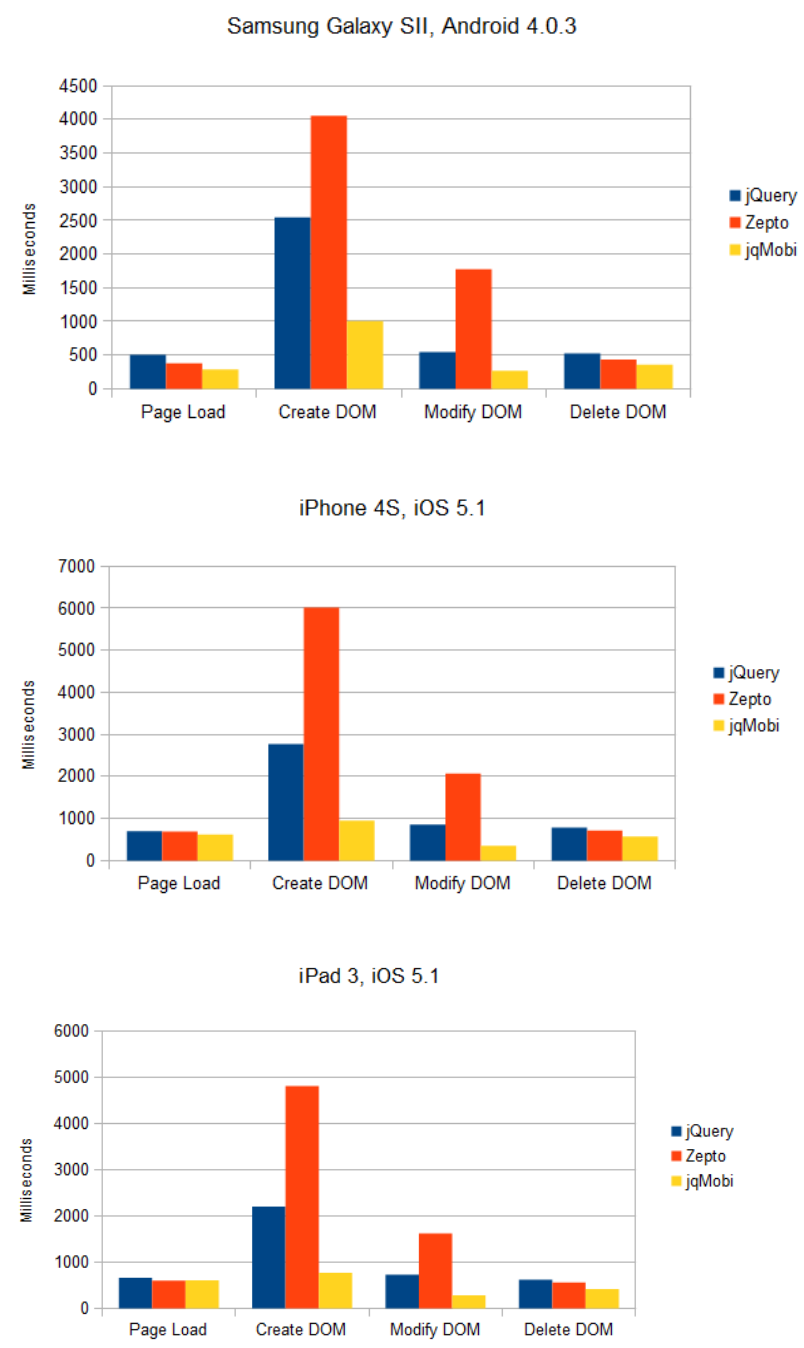
Results show that jqMobi outperforms the other libraries, being much faster than both jQuery and Zepto for DOM operations, and loading slightly faster. jQuery is in general faster for DOM operations than Zepto, but for some operations Zepto performs better. Zepto loads slightly faster than jQuery. Page loading time on iOS is faster when relaunching the app, because of the way iOS caches pages. For example, in our test on iPhone 4S, jqMobi loaded in 843 ms on first app start, and next time it loaded in $399 \mathrm{~ms}$. Note that the diagrams show the average of first and second load time.

\section{REFERENCES}

1. M. Asokan, "E-commerce websites with jQuery". International Journal on Computer Science and Engineering (IJCSE), Vol. 5 No. 03 Mar 2013.
2. A. Tirkar, "Trend Of E-commerce Technology \& Its Security Issues” Golden Research Thoughts Vol-3, Issue-2 (Aug 2013).

3. D.Cunningham, L. Thach, K. Thompson, "Innovative E-Commerce Site Design: A Conceptual Model to Match Consumer MBTI Dimensions to Website Design". Journal of Internet Commerce, Vol. 6(3) 2007

4. G.Minculete, g.Minculete, "approaches related to e-commerce models in the e-business". Revista academiei forţelor terestre nr. 1 (69)/2013

5. http://jsperf.com/. accessed Ocotber 25, 2013.

6. http://www.webperformancetoday.com/tag/aberdeen/. Accessed October 20, 2013.

7. R. Tassabehji, "Applying E-Commerce in Business". SAGE Publisher, May 2, 2003. ISBN 0761948759

8. C. Lindley, "jQuery Succinctly". Ebook by SyncFusion, 2013. 